\title{
Innovative management practices and their impact on local e-government performance: The Turkish provincial municipalities
}

\author{
Aykut Arslan \\ Faculty of Management, Halic University, Istanbul. E-mail: draykutarslan@gmail.com. \\ Accepted 14 June, 2011
}

\begin{abstract}
Contrary to popular belief which sees the government as reactive and resistant to change, the increasing emergence of innovative ideas particularly in the field of local services yielded a wide range of interactions. This was due to address new policy challenges, improve productivity, better serve and more fully engage a changing citizenry. Practicing new ideas triggered more innovativeness. The paradigm of NPM and later the phenomenon of e-government are well studied. However, the relationship among innovative management practices and their impact on e-government performances require a deeper understanding. Thus, our paper seeks to shed some light on this issue by exploring what type of local services were transformed online and at what level. Then, in accordance with the organizational dynamics of innovation, we developed hypotheses to inquire the impact of innovative management practices on local e-government performance of Turkish provinces. Mann-Whitney $U$ statistics were carried out to find out which of the groups that were statistically significant different from one another. The results indicated significant findings. The provincial local governments which adopted innovative management practices tend to have higher local e-government performances.
\end{abstract}

Key words: Local e-governments, Turkish provinces, new public management, public innovation, Turkey.

\section{INTRODUCTION}

Arslan (2009) argues that by responding to rapid changes in their environment and complexity in their governance, the Turkish local governments have been innovative in economic development policy management and strategic planning. The government efforts to transform themselves into much more performance focused organizations and the implementation of performance measurement systems and the management mentality that become the main component of the New Public Management (NPM) doctrine, support politicians and public servants in their decision making processes, accountability and result orientedness (Torres et al., 2006). On the other hand, organizational culture and climate are suggested to impact attitudes toward innovation adoption (Aarons, 2004; Frambach and Schillewaert, 2002). Once the organization is immersed in managerial innovation projects and when these yield positive outcomes, it may encourage and motivate inauguration of other initiatives such as e-government, too. We claim that in time, experiencing with the innovative management practices, culminated innovative culture and organizational climate will affect other managerial innovations positively. In the end, these will determine the impact on local economic and community development (Martin, 2000).

The reflection of innovative management practices on the Turkish local context is an under researched area. The aim of this paper is thus to shed some light on this issue by exploring what type of local services are transformed online and at what level. Then, in accordance with the organizational dynamics of innovation, we developed hypotheses to inquire the impact of innovative management practices on local e-government performances of Turkish provinces. We seek to address answers for the following questions:

1) How many of the assigned services by the laws \# 5393 and \#5216 are put online by the Turkish provincial 
municipalities?

2) And at what level?

3) Are there any correlations among innovative management practices, and do these innovative management practices have an impact on the local e-government performances of these provinces?

\section{LITERATURE REVIEW AND HYPOTHESES}

By stating out why innovative management is required in public sector, we put forth that innovative management practices are closely related to each other and together, they influence, and to some extent, even ensure the success of e-service implementations. Based on the extensive literature of e-government and innovative organizations, hypotheses are developed.

\section{The need for innovative management practices in public sector}

Given the rapid change and evolving of e-commerce in private sector, citizens are demanding better and more effective services. It is believed that innovation may assist finding new ways to reach citizens and ensure services with maximum value. Part of understanding why public sector innovation is an important initiative is to reach back and understand how it is different from previous initiatives that were aimed at reinventing public sectors. Sparked first in the 1980 s by developed countries, the NPM paradigm encourages the use of private sector management techniques in the public sector. In the 2000s, the government accelerated restructuring efforts in Turkey and various regulations have started to be established accordingly (Demir and Yavuz, 2009). The new laws \# 5393 and \# 5216 in particular, drew a framework for the local governments about mandated and nonmandated duties. A more recent law \# 5018 imposes public entities the responsibility for preparation of annual budgets based on strategic planning and performance measurement along with the law \# 5393 (Karabeyli, 2006). Innovative management practices such as strategic planning and performance management were introduced for the very first time. The NPM terminology comprising accountability, efficiency, effectiveness, governance, and transparency became the buzzwords of the bureaucracy.

\section{Local e-services}

E-service is a public service mediated electronically through a user interface that is generally available (Röstlinger and Cronholm, 2009). And in this respect, egovernment mostly comprises of e-services provided by the internet (Verdegem and Verleye, 2009) or also known as web based government services (Goings et al., 2003). Although there are several other channels (mobile, telephoning, digital TV, etc.) than the web based eservices, because the Internet is the prominent media (Reddick, 2005), this paper's focus will be on web enabled e-services (a.k.a. local e-government services).

E-government literature mostly deals with web enabled services drawn on content analysis of the websites and classifies them accordingly (Koh and Prybutok, 2003; Norris and Moon, 2005; West, 2001; Musso et al., 2000 as cited in Huang, 2007). And the results are heavily based on the US local context. However, this research builds on the legal framework inspired by local government laws in Turkey (\# 5393 and \# 5216). Unlike the other researches, we made the content analysis according to this legal framework. The extent of duties ranges from mandated to non-mandated as well as extra services.

Researchers investigate the development and sophistication of e-governments through stages ranging from two to five levels (Huang, 2007; Kachwamba and Hussein, 2009; Thakur, 2007). By grounding on the literature, in terms of e-government sophistication, this paper relies on two types of interaction and a transactional stage:

a. One-way interactive: information publishing (Level 1)

b. Two-way interactive: mutual (asynchronous or synchronous) (Level 2)

c. Transactional: e-commerce (Level 3)

Except the first one, each level aggregates a high use of technology and complex structure of interaction regarding citizens and local governments (Kachwamba and Hussein, 2009). The higher the level, the more complicated functions need to be provided, which demands more technological expertise and financial sources (Huang, 2007). The sequence is not linear as discussed earlier in literature (Thakur, 2007). One local government may be at the second level while another one may be at the initial stage (Kachwamba and Hussein, 2009).

One-way interactive e-government services are the basic types consisting of public policies, laws and regulation, reports, newsletters, and downloadable databases as well as basic information

As for the two-way interactive e-government services, public officials can be contacted via email, the website is updated regularly and provides downloadable or online filling forms for application or payment as well as audio or video capability for relevant public information, search tools, and online chats.

The last stage, transactional e- government services are comprised of e-commerce applications via secure links such as EDI-electronic data exchange, digital wallets, e-cash, mobile payment, e-checks, and epayment (Huang, 2007)(more prevalent).

\section{The bridge between innovative management practices and e-government}

Gordon (2002) argue that NPM gives e-government a 
fresh blood. That is; the adoption of e-government may trigger institutional reform initiatives since it is difficult to maintain strictly hierarchical channels of communication and control when every civil servant can collaborate efficiently and directly with anyone else via the Internet. Some (Schedler and Scharf, 2002) posits e-governments as NPM initiated changes due to its service oriented philosophy and elaborated this relationship further as a reinforcing one towards a reform paradigm (Homburg and Bekkers, 2005). Nevertheless, all these views indicate a strong mutual relationship, but rather theoretically. So, it is our paper's aim to provide empirical evidence on this issue.

\section{Quality management system implementations as innovative management practices}

Through a theoretical standpoint, not only e-government and total quality management (TQM) pursue some identical purposes, but they also share an important set of core concepts and principles (Moura E SÀ, 2009). Customer focus, process management and people involvement in particular, are key elements indicating a link between these two approaches. On the other hand, the goals of which managerial innovation practices assert such as accountability, transparency, efficiency, effectiveness, and responsiveness are the core concepts also commonly shared by all.

The diffusion of managerial innovations and outreach is a function of local governments' accumulated e-government effort over time. A local government's preexisting innovation capacity results in the development of institutional capability, which in turn encourages greater sophistication of continuous governmental digitalization.

Although the relationship between the implementation of quality management systems (QMSs); thatis, ISO 9001 , and the innovation capacity of the organizations has been broadly studied from a theoretical point of view (Castillo et al., 2008), there are not many empirical studies in the literature that are related to the impact of QMSs on the innovation capacity of public organizations particularly regarding e-government services. The literature holds different views in respect to the correlation between QMSs and innovation. Yaacob (2010) compared the performance of local authorities with two different levels of adoption of quality management (QM) and his study revealed that local authorities with high intensive QM secure better results as compared to local authorities with less intensive QM in performance dimensions of customer satisfaction and employee satisfaction. Quazi and Padibjo (1997) noted that many organizations striving to attain TQM have chosen QMSs certification as a stepping-stone to achieve this goal. This was also the case with the Turkish local governments. While investigating the web presence and e-government applications of the Turkish local governments, Arslan
(2007) found that TQM was perceived solely as QMSs certification by most of the local officials. In fact, by incorporating factors such as customer satisfaction and continual improvement, for instance ISO 9001:2000 moves closer to the principles of TQM than its predecessor, ISO 9001:1994, while retaining the discipline of third-party assessment, registration and surveillance. The ISO 9001:2000 standards are a specifically defined and documented set of quality principles phrased as "requirements" by the international standards body. Many of its requirements embrace various TQM tools and techniques. Another finding (Arslan, 2007) worth investigating, is the statements of the Turkish local governments (47 out of 208) that had either an ISO certificates, told that the total quality efforts were started along with e-government activities simultaneously.

The literature comprises vast amount of empirical research on the performance outcome of private sector, that is, financial performance, increase profitability; yet to date little research has been done that can indicate how ISO certificates affect local government organization's performance in the public sector in Turkey. But theoretically, we may assume that a growing number of local governments have adopted quality-oriented management processes as to provide better quality service, to deal better with fiscal stress and to improve efficiency (Kline, 1992).

Thus, following the predictions and evidence from prior research on the QMSs programs in private sector, our first hypothesis is:

$\mathrm{H}_{1}$ : Provincial local governments which adopted QMSs will likely show high innovative performances regarding local e-government services.

\section{Strategic planning as innovative management practice}

A local government's ability to plan strategically and fulfill its goals is used as a foundation for furthering a community's investment in strategic management through linking planning with measurement, budgeting, and accountability systems. The outcome is a community that thinks and acts strategically to achieve its long term desired goals. Arslan (2009) contends that strategic management has been used among the Turkish local governments for more than four years now, but little is known about how it is used and the results obtained. The Municipal Law of July 05, 2005 (\# 5393) requires the local governments with populations over 50,000 to develop strategic plans and tie them to budgets and performance measures. Although the law requires and enforces those local governments with populations over 50,000 to develop strategic plans, there are still some of them which have not prepared any. Governments have the option to compel action through regulatory actions that either 
punish or reward certain behaviors through government rules or regulations (Holden, 2006). While governments have the authority to enforce such regulatory action, there seems to be no indication of such for the Turkish context. May be, as Vinzant and Vinzant (1996) put it; to some local governments, strategic management might be "extremely" challenging with regard to the highly publicized resource allocation, lack of autonomy, and a critical political environment. Kwon (2006) asserted that lack of financial resources and information technology (IT) expertise among the local governments led to increase of a strategic perspective on IT utilization. Based on International City/County Management Association (ICMA) in 2002, he found that $66 \%$ of local governments lack technology/web staff in their governments and $47 \%$ lack technology/web expertise. The absence of these critical factors pushes smaller local governments to a disadvantage in developing interactive e-services. In this respect, the local governments should implement a strategy management to overcome these management difficulties of IT capacity to provide sophisticated eservices efficiently.

Arpaci and Arifoglu (2009) argue that the occurrence of a successful innovation associated with a product, service or process in some part of the organization's value chain, should be joined with a business design, which in turn is implemented with discipline and skill through innovation management. To sustain a successful innovation management, organizations are required to develop a sound strategic approach to the innovation. Some researches (Lihua and Zheng, 2005) found evidence on the influence of transformational leaderships and strategic planning on the success of e-government applications. They argue that organizational change has costs, benefits and risks, so strategic planning will be helpful to prepare the government organizations to deal with all kinds of uncertainties. Thus, a requirement for a strategic approach to innovation in the public sector should yield positive results. Therefore, we hypothesize:

$\mathrm{H}_{2}$ : Provincial local governments which adopted SPs (strategic plans) will likely show high innovative performances regarding local e-government services.

\section{Performance measurement as innovative management practice}

Although several drivers influence management decision making, especially in complex environments (Powers, 2009), performance measurement data is often expected to act as a key source for informing the improvement efforts of numerous management functions such as strategic planning and management, operational planning and management, communications with stakeholders, budgeting, human resource management, evaluation, and so on (Powers, 2009: 2). The main driver here is to monitor and improve the quality of public services (Kwon,
2006).

Performance measurement and performance management are different concepts often confusing the practitioners. Performance management is what you do with the information you have developed from measuring performance. Performance managing means using performance measurement information to manage your public capacity and processes (Lichiello, 1999: 13).

DeGroot (2005) emphasizes the significance of increasing efforts on performance in local public services. Performance management is the key to supporting the local leadership to deliver its vision, and to provide efficient and effective deployment of the resources. She also argues that local authorities that pursue performance management insistently are more likely to provide good services to local people, to concentrate on the services that matter most, and are quick to identify problems and find solutions (DeGroot, 2005: 3). Likewise, the municipal law \# 5393 and Public Financial Management and Auditing law \# 5018 incorporate performance measures and budgeting based on the performance outcome along with strategic planning in Turkey. However, not every local government strategic plan integrates performance management.

Even the ones which have performance management in place could not make any kind of meaningful use of the measures in their management and decision-making process.

This is because decision-making process is a complex set of sub-systems in which citizen preferences, political mandates, fiscal constraints, decisions made in previous years, and the professional norms of public administrators may interfere (Rivenbark and Kelly, 2003).

On the other hand, once applied and sustained successfully, performance management systems have the potential to transform governments due to their potential to improve the performance and accountability (Padovani et. al., 2009). Therefore, we hypothesize:

$\mathrm{H}_{3}$ : Provincial local governments which adopted PPs (performance plans) will likely show high innovative performances regarding local e-government services.

\section{METHODOLOGY}

There are 2959 municipalities or local governments in Turkey. The focus of our research is 81 provincial municipalities out of which 16 are Greater or Metropolitan municipalities whereas the rest, 65, is provincial centers. $46 \%$ of overall population lives in greater municipalities while 65 provincial municipalities comprise $13 \%$ (according to 2009 population census ${ }^{1}$ ). As of July 2005, new laws (\#5393 and \#5216) were put in place which mandates services for provincial and greater municipalities (Karabeyli, 2006). Same laws attribute services for the local governments on voluntarily basis (non-mandated). For the sake of our research framework, we categorized them as follows: Mandated duties, non-mandated duties, participatory services, and extra services (Table 1).

\footnotetext{
${ }^{1}$. http://www.mahalli-idareler.gov.tr/Mahalli/Istatistik.aspx.
} 
Table 1. Service categories and e-service levels.

\begin{tabular}{lcccc}
\hline \multirow{2}{*}{ Service category } & Level 1 & Level 2 & Level 3 & Total \\
\cline { 2 - 5 } & $\{\mathbf{N}(\%)\}$ & $\{\mathbf{N}(\%)\}$ & $\{\mathbf{N}(\%)\}$ & $\{\mathbf{N}(\%)\}$ \\
\hline Mandated & $828(80)$ & $140(13)$ & $71(7)$ & $1039(100)$ \\
Non-mandated & $99(86)$ & $15(13)$ & $1(1)$ & $115(100)$ \\
Participatory & $172(83)$ & $33(16)$ & $4(1)$ & $209(100)$ \\
Extra & $83(45)$ & $95(52)$ & $5(3)$ & $183(100)$ \\
\hline
\end{tabular}

Table 2. Descriptive statistics and correlation results.

\begin{tabular}{lccccc}
\hline Variable & $\mathbf{M}$ & $\mathbf{S D}$ & $\mathbf{1}$ & $\mathbf{2}$ & $\mathbf{3}$ \\
\hline QMS & 0.25 & 0.434 & 1 & $0.242^{*}$ & $0.229^{*}$ \\
SP & 0.59 & 0.494 & & 1 & $0.462^{\star *}$ \\
PM & 0.36 & 0.482 & & & 1 \\
\hline
\end{tabular}

$\mathrm{N}=81,{ }^{*} \mathrm{p}<0.05,{ }^{* *} \mathrm{p}<0.01$.

Participatory services contain both mandated and non-mandated services but the extra ones can be valued as more innovative due to their nature. We counted 63 services in all. Because of samplesize requirement, 81 sites were all used in the study (Cochran, 1977).

An ideal method, content analysis of web sites, deliveries, and strategies, is commonly used in literature (Zhao et al., 2010). This will help the researchers to make inferences by systematically and objectively recording the characteristics and capabilities of $\mathrm{e}$ government service sites. Two trained independent coders examined and coded the 81 websites for the relevant service from November 2010 to March 2011. To ensure objectivity and to avoid any potential bias, the author was not involved in the coding sessions as suggested in literature (Zhao et al., 2010). Inter rater reliability; Cohen's kappa was found as $87.3 \%$.

Meanwhile, the seasonal activity reports and service inventory tables, if published online, were also evaluated to make it sure not to miss any e-services provided. Each service on the list was assessed to find the sophistication level. For example, if a web site contains only publishing of a strategic plan it should be at one-way interactive level. But should it issue a strategic plan along with an opinion poll interrelated to the local strategy, then it is at the twoway interactive level. Any services not online were left empty.

Most of the strategic plans were obtained from the website of state planning organization. Yet, we did a thorough research on the Internet and the websites of those local governments, and if required, asked the officials not to miss any document. For the municipalities with QMSs certificates, another state organization, TSE (Turkish Standards Organization) database was used.

Correlation coefficients were computed to assess the relationships among the innovative practices. To test the homogeneity of variances Levene's tests are performed. Since the $p$-values are less than the critical value $(<0.05)$, the equality of variances is rejected and non-parametric tests are carried out. Mann-Whitney $U$ tests were conducted to evaluate the hypotheses that provincial local governments which adopted QMSs, SPs, and PPs will likely show higher innovative performances regarding local e-government services, on the average, than the ones which adopted none.

\section{ANALYSES AND RESULTS}

Means, standard deviations and inter-correlations for the study variables are displayed in Table 2 . The results indicate that QMS practices are positively correlated to SPs $(r=0.242, n=81, p<0.01)$ as well as to PMs $(r=$ $0.229, \mathrm{n}=81, \mathrm{p}<0.01$ ). It should also be noted that SPs are significantly and positively correlated with PMs ( $r=$ $0.462, \mathrm{n}=81, \mathrm{p}<0.01$ ).

Table 3 summarizes how the provincial local governments which adopted innovative management practices performed in delivering e-government services at each level. The results of the first Mann-Whitney $U$ test were in the expected direction and significant, $z=-4,142$, $p<.05, z=-3,813, p<.05$, and $z=-3,080, p<.05$. Municipalities with QMS practices at level one had an average rank of 59.88 , while municipalities without any implementation had an average rank of 34.81 . As for the second level, municipalities with QMS practices had an average rank of 59.22, while municipalities without any implementation had an average rank of 35.35. Lastly, municipalities with QMS practices at level three had an average rank of 59.88 , while municipalities without any implementation had an average rank of 34.81 .

The second Mann-Whitney $U$ test results were also as expected and significant, $z=-2,557, p<.05, z=-3,565, p$ $<.05$, and $z=-2,600, p<.05$. Municipalities with SPs at level one had an average rank of 46.53, while municipalities without any planning had an average rank of 32.95. As for the second level, municipalities with SPs had an average rank of 48.65, while municipalities without any planning had an average rank of 29.88 . Lastly, municipalities with SPs at level three had an average rank of 46.23 , while municipalities without any planning had an average rank of 33.39. The last MannWhitney $U$ test yielded significant results too; $z=-2,882$, $p<.05, z=-4,395, p<.05$, and $z=-3,296, p<.05$. Municipalities with PPs at level one had an average rank of 51.07, while municipalities without any plans had an average rank of 35.38. As for the second level, 
Table 3. The Mann-Whitney U test results.

\begin{tabular}{|c|c|c|c|c|c|c|c|c|}
\hline Variable & & $\mathbf{N}$ & Mean rank & Sum of ranks & Mann-Whitney U & Wilcoxon W & $\mathbf{Z}$ & P-value (two-side) \\
\hline \multicolumn{9}{|l|}{ QMS } \\
\hline \multirow{2}{*}{ L-1 } & 0 & 61 & 34.81 & 2123.5 & \multirow[t]{2}{*}{232.5} & \multirow[t]{2}{*}{2124} & \multirow[t]{2}{*}{-4.142} & \multirow[t]{2}{*}{0.000 * } \\
\hline & 1 & 20 & 59.88 & 1197.5 & & & & \\
\hline \multirow[b]{2}{*}{ L-2 } & 0 & 61 & 35.35 & 2156.5 & \multirow[t]{2}{*}{265.5} & \multirow[t]{2}{*}{2156} & \multirow[t]{2}{*}{-3.813} & \multirow[t]{2}{*}{0.000 * } \\
\hline & 1 & 20 & 58.22 & 1164.5 & & & & \\
\hline \multirow{2}{*}{ L-3 } & 0 & 61 & 36.72 & 2240 & \multirow[t]{2}{*}{349} & \multirow[t]{2}{*}{2240} & \multirow[t]{2}{*}{-3.08} & \multirow[t]{2}{*}{0.002 * } \\
\hline & 1 & 20 & 54.05 & 1081 & & & & \\
\hline \multicolumn{9}{|c|}{ STRATEGIC } \\
\hline \multirow{2}{*}{$\mathrm{L}-1$} & 0 & 33 & 32.95 & 1087.5 & \multirow[t]{2}{*}{526.5} & \multirow[t]{2}{*}{1088} & \multirow[t]{2}{*}{-2.557} & \multirow[t]{2}{*}{0.011 * } \\
\hline & 1 & 48 & 46.53 & 2233.5 & & & & \\
\hline \multirow{2}{*}{ L-2 } & 0 & 33 & 29.88 & 986 & \multirow[t]{2}{*}{425} & \multirow[t]{2}{*}{986} & \multirow[t]{2}{*}{-3.565} & \multirow[t]{2}{*}{0.000 * } \\
\hline & 1 & 48 & 48.65 & 2335 & & & & \\
\hline \multirow{2}{*}{ L-3 } & 0 & 33 & 33.39 & 1102 & \multirow[t]{2}{*}{541} & \multirow[t]{2}{*}{1102} & \multirow[t]{2}{*}{-2.6} & \multirow[t]{2}{*}{0.009 * } \\
\hline & 1 & 48 & 46.23 & 2219 & & & & \\
\hline \multicolumn{9}{|c|}{ PERFORM } \\
\hline \multirow{2}{*}{$\mathrm{L}-1$} & 0 & 52 & 35.38 & 1840 & 462 & 1840 & -2.882 & 0.004 * \\
\hline & 1 & 29 & 51.07 & 1481 & & & & \\
\hline L-2 & 0 & 52 & 32.51 & 1690.5 & 312.5 & 1690 & -4.395 & 0.000 * \\
\hline L-2 & 1 & 29 & 56.22 & 1630.5 & & & & \\
\hline $1-3$ & 0 & 52 & 35.03 & 1821.5 & 443.5 & 1822 & -3.296 & 0.001 * \\
\hline L-O & 1 & 29 & 51.71 & 1499.5 & & & & \\
\hline
\end{tabular}

${ }^{*} p<0.05$. Total $N=81$

municipalities with PPs had an average rank of 56.22, while municipalities without any plans had an average rank of 32.51. Lastly, municipalities with PPs at level three had an average rank of 51.71 , while municipalities without any plans had an average rank of 35.03 .

\section{DISCUSSION}

Svara (2008) points out the importance of innovation in government, and claims that the types, level, and impact of innovation in government and the organizational features associated with variation in innovation is limited, particularly through scholarly view. He defines the term "innovation" as "the introduction of new or alternation of existing practices with the intention of producing positive results by referring to Damanpour and Evans (1984)" (Svara, 2008: 2). The two forms of innovation are (a) adoption of "standard" or "leading" new approaches from outside the organization, for example, e-government services, and (b) invention of new approaches or substantial modification of methods or practices from other organizations to create new approaches, that is, "reinvention" (Svara, 2008: 2). However, he continues to debate that technological innovation in public agencies are referring maturational models and that these models tend to dominate practitioner discussions and scholarly research (Hiller and Bélanger 2001; Layne and Lee, 2001; UN and ASPA, 2002 as cited in Svara, 2008). The maturational model fits well with the notion of incrementalism, which suggests that government innovation tends to occur in small steps over extended periods (Brown, 2007). Not only has the notion of incrementalism been vastly applied to define e-government maturity (a.k.a. sophistication), but it can also help us to describe the mutual link among innovative management practices 
and e-services. In other words, each successful experience with an innovative management practice may lead to adoption of a new one.

On the other hand, by referring Moore and Hartley (2008), Walker et al. (2010) put forth the idea of blurriness and dimensionality of innovation types in the public sector. The adoption of innovations may occur simultaneously instead of following a linear trajectory. That is; the successful adoption of one innovation may be dependent upon another (Walker et al., 2010: 14). They found a positive relationship between management innovations and performance management in English local governments. There are also evidences on the positive relationship between the organizational innovation climate and Information Systems innovation usage from private enterprises (Min, 2009). Many studies also suggest that learning is an antecedent of innovativeness. That is; innovation connotes the generation and implementation of new ideas, processes or products (Chen et al., 2009). Our study corroborates these findings from the public sector perspective. In a previous research among the Turkish local e-Governments, Arslan (2007) found some anecdotal evidences on the interaction of innovative practices. He claimed the Turkish local egovernment services were either started simultaneously with TQM efforts regarding QMSs implementations or experiencing with those innovative projects for a certain period of time may have caused the Turkish local governments to start e-government services. This may assisted them to develop a culminated innovative culture and an organizational climate which resulted in triggering of other managerial innovations.

It is also possible that when those local governments started e-government initiatives at first, they may have learned the basics of project management during the course; thus, may also have led the way of new innovative ideas. In other words they may have co-existed in an evolutionary process. The emergence and evolution of an innovation system rests on a co-evolutionary process (Fagerberg et al., 2009), in which, in our case, the implementation of new innovative management projects interacts with and affects the development of e-government services. Fagerberg et al. (2009) explain these coevolutionary processes in terms of path dependencies of various sorts, for example, processes that systematically favor some types of activities (or solutions or ideas). Moreover, they are also time-dependent. Many new ideas may emerge regardless of time, "but only those that are well adapted to the contemporary selection environment are likely to be applied and form the basis for continuing adaptation and improvement" (Fagerberg et al., 2009: 4).

To sum up, we can conclude that we found strong evidences as to whether innovative management projects might have an impact on e-government projects. The same conclusions can be drawn for the mutual relationships of innovative practices. But still, we need further analyses for the anecdotal claims as to whether those projects have started simultaneously or whether each project has paved a way to one another.

Then again, the endeavor of some local governments to deliver e-government services without any other innovative management practices deserves a detailed investigation. The future research may look into this and figure out the antecedents of absence of the co-evolutionary processes among the local governments.

\section{REFERENCES}

Aarons GA (2004). Mental health provider attitudes toward adoption of evidence-based practice. The evidence-based practice attitude scale (EBPAS). Ment. Health Serv. Res., 6: 61-74.

Arpaci I, Arifoğlu A (2009). E-transformation and technological innovation in Turkey. Proceedings of the European and Mediterranean conference on information systems (EMCIS). 13-14 July, İzmir, Turkey.

Arslan A (2007). Turkish Local e-Governments: a Longitudinal Study. Elect. J. e-Gov., 5(2): 95-106.

Arslan A (2009). A Strategic Orientation Model for the Turkish Local eGovernments. Proceedings of 1st International conference on eGovernment and eGovernance. 12-13 March, Ankara.

Brown MM (2007). Understanding e-government benefits: an examination of leading-edge local governments. Ame. Rev. Pub. Adm., 37(2): 178-197.

Castillo SM, Casadesús M, Karapetrovic S, Heras I, Martín I (2008). An empirical study of the impact of management standards on the innovation processes. 11th QMOD conference proceedings. 33. Dahlgaard-Park, Su Mi; Dahlgaard, Jens J. (eds.). Quality management and organizational development attaining sustainability from organizational excellence to sustainable excellence. 20-22 August, Helsingborg, Sweden.

Chen J, Liu Z, Wu N (2009). Relationships between organizational learning, innovation and performance: an empirical examination. International conference on information management, Innov Manage. Ind. Eng., 3: 488-492.

Cochran WG (1977). Sampling techniques ( $3^{\text {rd }}$ ed.). New York, NY: John Wiley and Sons.

DeGroot L (2005). Generating improvement from within: the role of the improvement and development agency for local government. Loc. Gov. State, 31(5): 677-682.

Demir H, Yavuz A (2009). Cadastral services in Turkey within the framework of new public management, Afr. J. Bus. Manage., 3(10): 582-590.

Fagerberg J, Mowery D, Verspagen B (2009). Innovation systems, path dependency and policy: The coevolution of science, technology and innovation policy and industrial structure in small, resource -based economy. TIK Working Papers on innovation studies. 20080624. Retrieved from: http://ideas. repec.org/s/tik/inowpp.html.

Frambach RT, Schillewaert N (2002). Organizational innovation adoption: a multi-level framework of determinants and opportunities for future research. J. Bus. Res., 55: 163-176.

Goings DA, Young D, Hendry SH (2003). Critical factors in the delivery of e-government services: perceptions of technology executives. Commun. Int. Inform. Manage. Assoc., 3(3).

Gordon TF (2002). E-government: introduction. Special theme: egovernment. ERCIM news online edition, p. 48. Retrieved from: http://www.ercim.eu/publication/Ercim_News/enw48/intro.html.

Holden SH (2006). A model for increasing innovation adoption: lessons learned from the IRS e-file program. Innovation series. IBM center for the business of government. Retrieved from: http://www.businessofgovernment.org/sites/default/files/HoldenRepor t2.pdf.

Homburg V, Bekkers V (2005). E-government and NPM: a perfect marriage? The information ecology of e-government. V. J. J. M. Bekkers and V.M.F.Homburg (Eds). E-gov. Inst. Technol. Innov. Public Adm., IOS Press, 9: 155-170.

Huang Z (2007). A comprehensive analysis of U.S. counties' eGovernment portals: development status and functionalities. Eur. J. 
Inform. Syst., 16: 149-164.

Kachwamba M, Hussein A (2009). Determinants of e-government maturity: Do organizational specific factors matter? J. US-China Pub. Adm., 6(7).

Karabeyli L (2006). Belediyelerde Performans Yönetimi (Performance Management in Municipalities), Birlik J. p. 1. Retrieved from: www.iabb.gov.tr/resimler/ekler/457c545a9ded88f_ek.pdf?dergi=1.

Kline JJ (1992). Total quality management in local government. Gov. Financ. Rev., 8(4).

Kwon M (2006). Strategic planning utilization in local governments: Florida city governments and agencies, unpublished $\mathrm{PhD}$. dissertation, the Florida State university college of social sciences. Retrieved from: http://gateway.proquest.com/ openurl\%3furl ver= Z39.88-2004\%26resdat=xri:pqdiss\%26rft_val_fmt=info:ofi/fmt:kev: $\mathrm{mtx}$ :dissertation\%26rft dat=xri:pqdiss:3216506.

Lichiello P (1999). Guidebook for performance measurement. Seattle, WA: turning point resources on performance management, national program office, university of Washington.1. Retrieved from: http://www.turningpointprogram.org/Pages/pdfs/perform_manage/pm c_guide.pdf.

Lihua W, Zheng Q (2005). Internet Use and E-Government Performance: A Conceptual Model, $9^{\text {th }}$ Pacific-Asia Conference on Information Systems, July 7-10, Bangkok, Taiwan.

Martin J (2000). Innovation strategies in Australian local government: occasional paper 4, Melbourne, Australian Housing and Urban Research Institute. Retrieved from: http://www.ahuri.edu.au/ global/docs/innov_localgov.pdf.

Min $Q$ (2009). An empirical study on the effect of information system innovation usage on performance: based on the innovation climate perspective. International conference on management science \& engineering. September 14-16, Moscow, Russia.

Moura ESP (2009). E-government implementation and total quality management adoption: an empirical study in the Portuguese municipalities. 13th IRSPM (The International Research Society for Public Management) conference proceedings. International center for business and politics. Copenhagen Business School. 6-8 April, Copenhagen, Denmark.

Padovani E, Yetan A, Orell RL (2009). Municipal performance measurement in practice: which factors matter? IPMN conference, Seoul National University, Seoul, June 23-24, p. 200.

Powers LC (2009). A framework for evaluating the effectiveness of performance measurement systems. Real World Systems Research Series 2009:1. Retrieved from: http://ssrn.com/abstract=1371158.

Quazi HA, Padibjo SR (1997). A journey towards total quality management through ISO 9000 certification - a Singapore experience. TQM Mag., 9(5): 364-371.
Reddick CG (2005). Citizen interaction with e-government: From the streets to servers? Gov. Inform. Q., 22(2005): 38-57.

Rivenbark WC, Kelly JM (2003). Management innovation in smaller municipal government. State Local Gov. Rev., 35(3): 196-205.

Röstlinger A, Cronholm S (2009). Design criteria for public e-services, 17th European conference on information systems. Retrieved from http://www.ecis2009.it/papers/ecis2009-0659.pdf.

Schedler K, Scharf M (2002). Exploring the interrelations between electronic government and the new public management. Book chapter of towards the e-society. Schmid, B., Stanoevska-Slabeva, K., and Tschammer (Eds). 74: 775-788. IFIP International Federation for Information Processing. Springer Boston. Retrieved from: http://dx.doi.org/10.1007/0-306-47009-8 57.

Svara JH (2008). A Study of the Scope and Dynamics of Innovation in City Government: A Literature Review and Exploration of SinoAmerican Differences. Paper presented at Annual Conference of American Society for Public Administration, March 10. Retrieved from: urbaninnovation.asu.edu/academic-network/pdf/Svara ASPA2008.doc.

Thakur D (2007). The development of E-government at the county and city levels in the United States. Paper presented at science and technology in society: an interdisciplinary graduate student conference. Washington DC, March 31- April 1.

Torres L, Pina V, Yetano A (2006). Determinants of strategic management implementation in local governments: an international setting. Workshop 1: performance of performance budgeting. International conference: a performing public sector. The second transatlantic dialogue. Leuven (Belgium), 1-3 June.

Verdegem P, Verleye G (2009). User-centered e-government in practice: a comprehensive model for measuring user satisfaction. Gov. Inform. Q., 26: 487-497.

Vinzant JC, Vinzant DH (1996). Strategic management and total quality management: challenges and choices. Pub. Adm. Q., 20(2): 201.

Walker RM, Damanpour F, Devece CA (2010). Management innovation and organizational performance: the mediating effect of performance management. J. Public Adm. Res. Theory, 21(2): 367-386.

Yaacob Z (2010). Performance of local authorities: analysis on two different levels of quality adoption. Afr. J. Bus. Manage., 4(14): 31693177.

Zhao JJ, Zhao SY, Zhao SY (2010). Opportunities and threats: a security assessment of state e-government websites. Gov. Inform. Q., 27(1): 49-56. 